\title{
Analysis of Patients Who Underwent Hemodialysis in the Emergency Department
}

\author{
Acil Serviste Hemodiyaliz Endikasyonu Konulan Hastaların Analizi
}

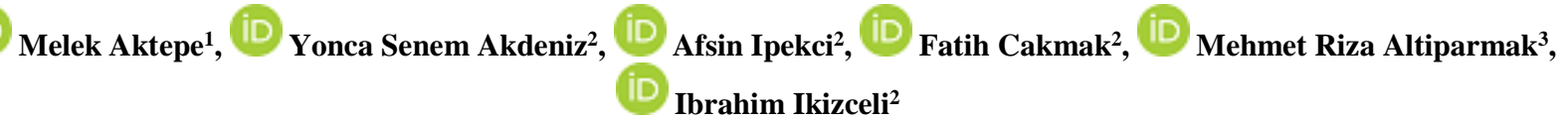

1- . Sağlık Bakanlığı, İstanbul Taksim Eğitim ve Araştırma Hastanesi, Acil Tıp Kliniği, İstanbul, Turkey. 2- İstanbul Universitesi-Cerrahpaşa, Cerrahpaşa Tıp Fakültesi, Acil Tıp Anabilim Dalı, İstanbul, Turkey. 3- İstanbul Universitesi-Cerrahpaşa, Cerrahpaşa Tıp Fakültesi, İç hastalıkları Anabilim Dalı, Nefroloji Bilim Dalı, İstanbul, Turkey.

\section{ABSTRACT}

Objectives: Hemodialysis is a life-saving treatment in patients with acute kidney injury. We aimed to compare the etiologic, laboratory, and clinical status and mortality rates of patients who underwent hemodialysis for the first time, as well as to determine the factors impacting mortality.

Material and Method: 95 patients who apply to the emergency room and underwent hemodialysis for the first time in our hemodialysis unit between 1.1.2017 and 1.1.2018 were enrolled in this retrospective study. The patients were evaluated in terms of demographic, clinical, and laboratory data, dialysis indications, the mortality rate for 30 days, kidney disease status, and causes of death.

Results: \%62.1 of patients were male and $37.9 \%$ were female and the mean age was 62.28 years. Metabolic acidosis and creatinine increase (75\%) were the most cause of dialysis. $41.1 \%$ of patients died in 30 days. The most common cause of death was complications due to underlining concomitant illnesses like malignancy (64.1\%). $7.4 \%$ of patients were recovered completely, $28.4 \%$ of patients had chronic renal disease without any renal replacement therapy, $64.2 \%$ of patients were dialysis patients at the discharge from the hospital.

Conclusion: Most of the patients who access the emergency room, because of anuria, hypervolemia, hyperpotasemia, and uremic symptoms, is taken to hemodialysis. These patients have approximately $40 \%$ mortality rate in 30 days of survival, and the primary cause of mortality is complications due to underlining concomitant diseases.

ÖZET

Amaç: Acil hemodiyaliz akut böbrek yetmezliği oluşan hastalarda hayat kurtarıcı bir tedavidir. Çalışmamızda acil serviste ilk kez hemodiyaliz tedavisi gören hastaların demografik ve klinik özellikleri ile beraber mortalitelerini etkileyen faktörlerin incelenmesi amaçland.

Gereç ve Yöntem: Retrospektif olarak yapılan bu çalışmaya hastanemiz acil servisine başvuran ve hemodiyaliz ünitesinde, 1.1.2017 ile 1.1.2018 tarihleri arasında ilk kez hemodiyalize alınan 95 hasta alındl. Hastalar demografik, klinik ve laboratuvar verileri, diyaliz endikasyonlarl, 30 günlük sağ kalımları. yaşayan hastaların renal durumları, ölen hastaların ölüm sebepleri açısından değerlendirildi.

Bulgular: Hastaların \%62.1'i erkek, \%37.9'u kadın, yaş ortalaması 62.28 yıl saptandı. Hastaların en sık diyalize alınma sebepleri metabolik asidoz ve kreatinin yüksekliği (\%75) idi. Hastaların \%41.1' inin 30 gün içerisinde öldüğü görüldü. En sık ölüm sebebinin \%64.1 malignite gibi altta yatan hastalıklara bağlı komplikasyonlar olduğu görüldü. Hastaların \%7.4 ü tam iyileşme, \%28.4 ü diyalize ihtiyaç duymayan kronik böbrek hastalı̆̆

Sonuç: Acil servise başvuran ve akut böbrek hasarl saptanan pek çok hasta anüri, hipervolemi, hiperpotasemi ve üremik bulgular nedeniyle hemodiyalize alınmaktadır. Bu hastaların otuz günlük mortalite oranlarl yüksektir ve en sik mortalite sebebi malignite gibi altta yatan hastalıklara bağlı komplikasyonlardır.
\end{abstract}

\section{GIRIS}

Hemodiyaliz, yarı geçirgen membran aracılığıyla hastanın kanı ve uygun diyaliz solüsyonu arasında sıv1solüt değişimini temel alan ve hastada mevcut olan sıv1-solüt dengesizliğinin normal değere yaklaştırılmasını amaçlayan bir tedavi şeklidir (1).

Avrupa Böbrek Derneği-Avrupa Diyaliz ve Transplant Derneği (ERAEDTA) raporlarına göre; 2015 senesi 81.327 son dönem böbrek hastalığı (SDBH) vakasında renal replasman tedavisine başlanmış, bu da bir milyon nüfus başına 119' luk bir insidans oranına denk gelir.
Keywords:

Emergency department. Acute kidney injury,

Dialysis.

Anahtar Kelimeler:

Acil servis,

Akut böbrek hasarl, Diyaliz.
Renal Replasman Tedavisi (RRT) yöntemlerine bakıldığında \%85 hemodiyaliz, \%10 periton diyalizi, \%5 böbrek nakli olduğu görülür (2). Türk Nefroloji Derneği (TND) 2016 raporlarına göre RRT gerektiren SDBH nokta prevalansını bir milyon nüfus başına 930 , RRT insidansını bir milyon nüfus başına 140 olarak görülmüştür. Ülkemizde daha sik uygulanan RRT yöntemi hemodiyalizdir (3).

Akut böbrek hasarı geniş bir etyoloji yelpazesinde görülen böbrek fonksiyonlarındaki düşüş ve Glomerüler filtrasyon hızının (GFH) saatler veya

Correspondence: Yonca Senem Akdeniz, İstanbul Universitesi-Cerrahpaşa, Cerrahpaşa Tıp Fakültesi, Acil Tıp Anabilim Dalı, İstanbul, Turkey. E-mail: ysa@istanbul.edu.tr

Cite this article as: Aktepe M, Akdeniz YS, Dr. Afsin Ipekci A, Cakmak F, Altiparmak MR, Ikizceli I. Analysis of Patients Who Underwent Hemodialysis in the Emergency Department. Phnx Med J. 2020;2(3):145-151. 


\section{Aktepe et al.}

Tablo 1: Hastaların yaş ortalamaları ve dağılımları

\begin{tabular}{lll}
\hline $\begin{array}{l}\text { Demografik } \\
\text { özellikler }\end{array}$ & & n (\%) \\
\hline \hline Yaş (yıl) & $\begin{array}{l}\text { Min-Mak } \\
\text { (Medyan) }\end{array}$ & $18-97(64)$ \\
& Ort $\pm S D$ & $62,28 \pm 15,96$ \\
\hline Cinsiyet & Kadın & $36(37,9)$ \\
& Erkek & $59(62,1)$ \\
\hline
\end{tabular}

günler içerisinde azalmasıyla kanda nitrojen yıkım ürünlerinin birikimiyle sonuçlanan bir sendromdur (4).

Akut böbrek hasarı (ABH) ve kronik böbrek hastalığ1 (KBH) hastalarında belirli klinik durumların varlığında hemodiyaliz tedavisi hayat kurtarıcı bir tedavi yöntemidir. Diüretik tedavisine yanıt vermeyen volüm yüklenmesi, medikal tedaviye yanıtsız hiperkalemi, metabolik asidoz, ensefalopati, perikardit ya da kanama diatezi gibi üremik durumlar hemodiyaliz endikasyonlarıdır (5).

ABH tanıs1 konulan kliniklerden biri de acil servislerdir. Böbrek fonksiyonları bozulma riski altında olan ve bu fonksiyonları farklı derecelerde bozulmuş olan hastaların ilk değerlendirilmesindr acil hekiminin rolü, asemptomatik ancak $\mathrm{ABH}$ açısından riskli hastaları belirleyerek bu hastaları $\mathrm{ABH}$ 'den korumak, böbrek yetmezliğinin metabolik etkilerini tedavi etmek, devam eden hasarı önlemek ve iatrojenik hasardan korumaktır.

$\mathrm{Bu}$ çalışmada Cerrahpaşa Tıp Fakültesi Acil Tıp Kliniğine çeşitli şikâyetlerle başvuran ve yapılan tetkikleri neticesinde acil diyaliz endikasyonu konulan hastaların demografik özellikleri, klinik ve laboratuvar bulguları, renal durum, ölüm oranları ve bunları etkileyen faktörlerin belirlenmesi amaçlandı.

\section{GEREÇ VE YÖNTEM}

$\mathrm{Bu}$ çalışma 31887016-604.01.01-62984 numaralı etik kurul onayı alındıktan sonra İstanbul ÜniversitesiCerrahpaşa Cerrahpaşa Tıp Fakültesi Acil Tıp Anabilim Dalında 01.01.2017-01.01.2018 tarihleri arasında acil servise başvuran ve nefroloji uzmanı tarafindan hemodiyaliz endikasyonu konulan hastaların demografik ve klinik özelliklerinin retrospektif olarak incelenmesi yöntemiyle gerçekleştirilmiştir. Acil servise başvuran, acil diyaliz endikasyonu konulan, daha önce hiç diyalize girmemiş ve 18 yaş üstü hastalar çalışmaya dâhil edilmiştir. Daha önce herhangi bir sebeple diyalize girmiş hastalar ve yeterli klinik bilgiye ulaşılamayan hastalar çalışma dışı bırakılmıştır.

Hastaların demografik özellikleri, başvuru şikâyetleri, böbrek hastalığı tipi, diyaliz endikasyonu, eşlik eden hastalıklar, altta yatan nedenler, yatış süreleri, 30 günlük mortaliteleri ve taburculuk sonrası durumları incelendi.

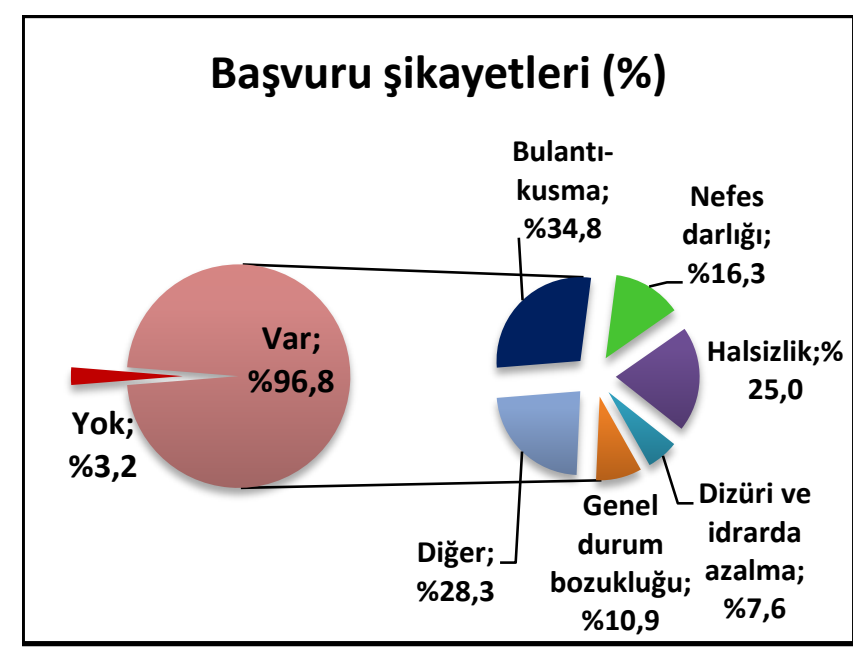

Şekil 1: Başvuru şikâyetlerinin dağılımı

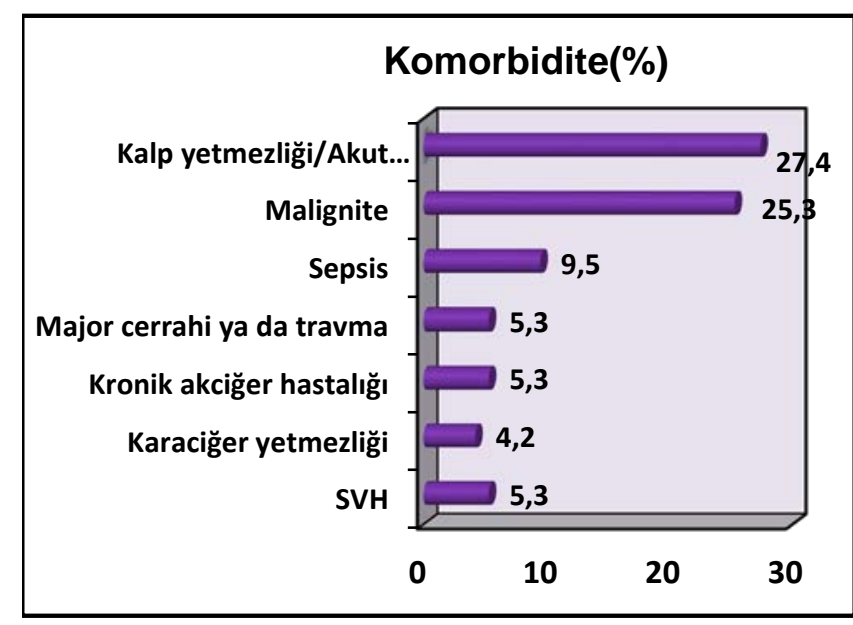

Şekil 2: Komorbidite dağılımı

İstatistiksel analizler için NCSS (Number Cruncher Statistical System) 2007 (Kaysville, Utah, USA) programı kullanıldı. Çalışma verileri değerlendirilirken tanımlayıcı istatistiksel metodlar (ortalama, standart sapma, medyan, frekans, oran, minimum, maksimum) kullanıldı. Nicel verilerin normal dağılıma uygunluklar1 Kolmogorov-Smirnov, Shapiro-Wilk testi ve grafiksel değerlendirmeler ile sınanmıştır. Normal dağılım gösteren nicel verilerin iki grup karşılaştırmalarında Student-t Test, normal dağılım göstermeyen verilerin iki grup karşılaştırmalarında ise Mann Whitney-U testi kullanıldı. Normal dağılım göstermeyen üç ve üzeri grupların karşılaştırmalarında ise Kruskal Wallis test kullanıldı. Nitel verilerin karşılaştırılmasında ise Pearson Ki-Kare testi, FisherFreeman-Halton Exact testi ve Fisher's Exact test kullanıldı. Anlamlılık en az $\mathrm{p}<0.05$ düzeyinde değerlendirildi.

\section{BULGULAR}

Çalışma döneminde kliniğimize \%37.9'u (n=36) kadın, \%62.1'i $(n=59)$ erkek olmak üzere toplam 95 olgu 
Tablo 2: Diyaliz Endikasyonları ve Ek Hastalıkların Dağılımı

\begin{tabular}{|c|c|c|}
\hline & & n (\%) \\
\hline \multirow[t]{6}{*}{$\begin{array}{l}\cdot \text { Diyaliz } \\
\text { endikasyonları }\end{array}$} & $\begin{array}{l}\text { Metabolik asidoz ve } \\
\text { kreatinin yüksekliği }\end{array}$ & $72(75.8)$ \\
\hline & Hiperkalemi & $8(8.4)$ \\
\hline & Hipervolemi & $22(23.2)$ \\
\hline & Postrenal ABH & $3(3.2)$ \\
\hline & Hiperkalsemi & $5(5.3)$ \\
\hline & $\begin{array}{l}\text { Üremik semptomlar } \\
\text { ve üremik perikardit }\end{array}$ & $10(10.5)$ \\
\hline \multirow[t]{7}{*}{-Ek hastalıklar } & Malignite & $26(27.4)$ \\
\hline & Hipertansiyon & $41(43.2)$ \\
\hline & Diyabet & $31(32.6)$ \\
\hline & Kardiak hastalıklar & $26(27.4)$ \\
\hline & $\begin{array}{l}\text { Renal parankimal } \\
\text { hastalıklar }\end{array}$ & 49 (51.6) \\
\hline & Postrenal nedenler & $8(8.4)$ \\
\hline & Diğger hastalıklar & $29(30.5)$ \\
\hline
\end{tabular}

başvurmuştur (Tablo 1). Olguların yaşları 18 ile 97 arasında değişmekte olup, ortalama $62.28 \pm 15.96$ yıldır.

Başvuru şikâyetleri incelendiğinde, olguların $\% 96.8$ 'inde $(n=92)$ başvuru şikâyeti vardır ve \%34.8 $(\mathrm{n}=32)$ ile bulantı-kusma ilk sırada tespit edilmiştir (Şekil 1).

Olguların diyaliz endikasyonları ve ek hastalıkları incelendiğinde, diyaliz endikasyonlarında en sık \%75.8 ile $(n=72)$ metabolik asidoz ve kreatinin yüksekliği ve $\% 23.2(n=22)$ ile hipervolemi tespit edilmiştir (Tablo 2). Ek hastalıklar yönünden en sık renal parankimal hastalık (\%51.6) ve hipertansiyon (\%43.2) tespit edilmiştir (Tablo 3).

Olgular komorbiditeler yönünden incelendiğinde, olgularda en s1k \%27.4 (n=26) ile kalp yetmezliği/ Akut myokard enfarktüsü ve \%25.3 $(n=24)$ ile malignite tespit edilmiştir (Şekil 2).

Tedavi sonrası renal durum yönünden incelendiğinde, olguların \%7.4'ünde $(n=7)$ tam iyileşme, \%28.4'ünde $(n=27)$ diyalize ihtiyacı olmayan kronik böbrek yetmezliği, \%64.2'sinde $(\mathrm{n}=61)$ diyalize ihtiyacı olan kronik böbrek yetmezliği olduğu görülmektedir (Şekil $3)$.

Olgular 30 günlük mortalite yönünden incelendiğinde, olguların \%41.1'inde $(n=39)$ mortalite tespit edilmiş olup nedenleri incelendiğinde 25 (\%64.1) olgu ile enfeksiyon ilk sırada tespit edilmiştir (Şekil 4).

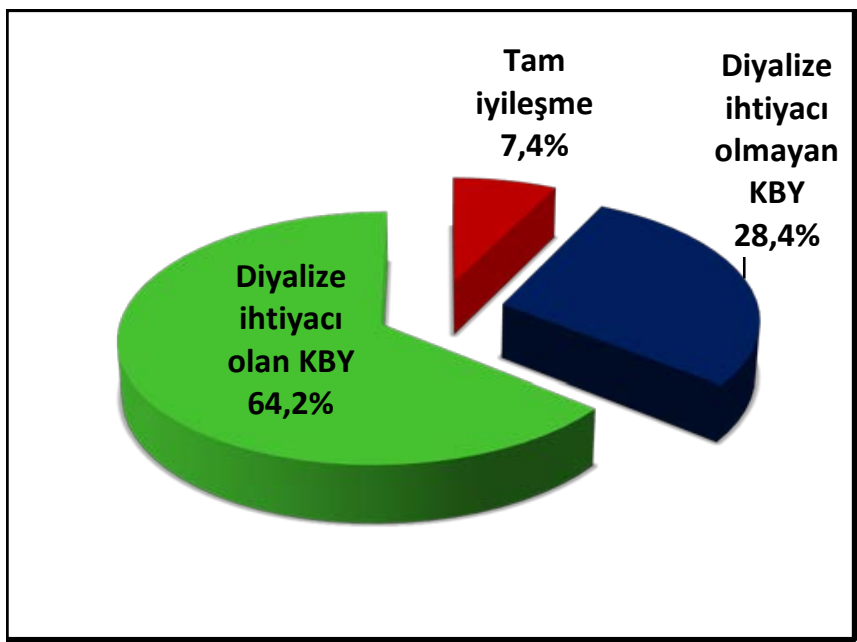

Şekil 3: Tedavi sonrası renal durum dağılımı

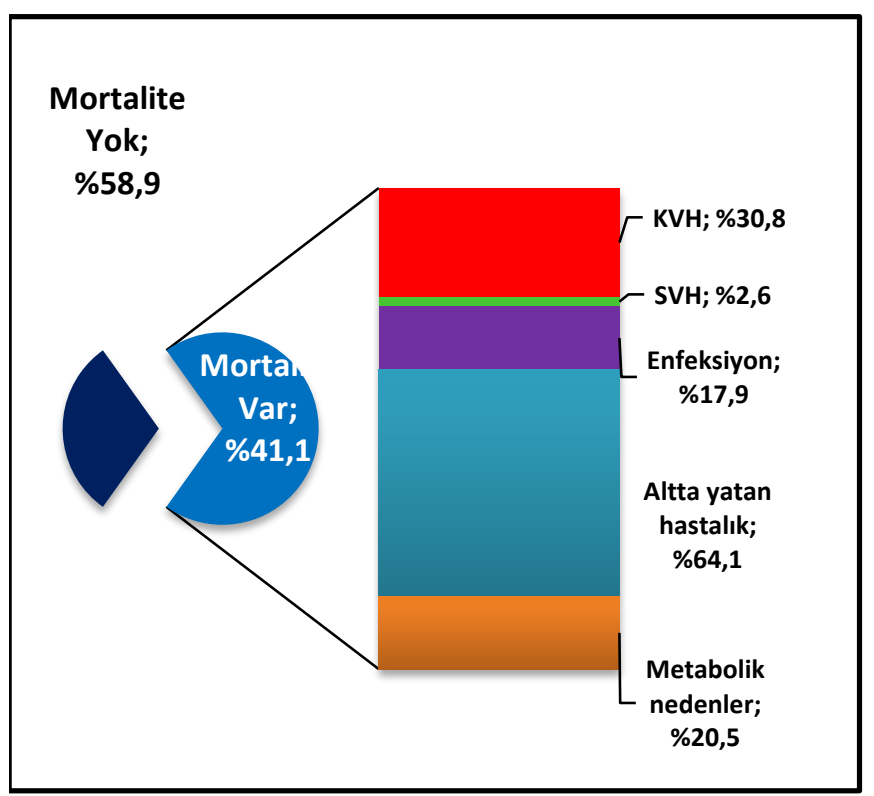

Şekil 4: Mortalite oranı ve nedenlerinin dağılımı

Mortaliteye göre olgular incelendiğinde, ölen hastaların yaşları istatistiksel olarak anlamlı yüksek ve genel durum bozukluğu ile başvuran hastalarda mortalite oranı istatistiksel olarak anlamlı yüksek tespit edildi (Tablo 4).

Olgularda diyaliz endikasyonlarından metabolik asidoz ve kreatinin yüksekliği görülme oranına göre renal durumları arasında istatistiksel olarak anlamlı farklılık saptanmıştır $(p=0.044 ; p<0.05)$. Diyalize ihtiyacı olan $\mathrm{KBH}$ olgularında metabolik asidoz ve kreatinin yüksekliği görülme oranı, tam iyileşen olgulardan daha yüksektir (Tablo 4).

Olgularda diyaliz endikasyonlarından hiperkalsemi görülme oranına göre renal durumları arasında istatistiksel olarak anlamlı farklılık saptanmıştır $(p=0.002 ; p<0.01)$. Tam iyileşen ve diyalize ihtiyacı olmayan $\mathrm{KBH}$ olgularında hiperkalsemi görülme oranı, diyalize ihtiyacı olan KBH olgularından daha yüksektir (Tablo 5). 
Tablo 3: Akut Böbrek Hasarı ve Kronik Böbrek Hastalığına İlişkin Dağılımlar

\begin{tabular}{|c|c|c|}
\hline & & n (\%) \\
\hline \multirow{2}{*}{$\begin{array}{l}\text { Akut böbrek } \\
\text { hasarı (ABH) }\end{array}$} & Yok & $1(1.1)$ \\
\hline & Var & 94 (98.9) \\
\hline \multirow{3}{*}{$\begin{array}{l}\text { Akut böbrek } \\
\text { hasarı nedeni } \\
(\mathrm{n}=94)\end{array}$} & Prerenal & $75(79.8)$ \\
\hline & Renal & $13(13.8)$ \\
\hline & Postrenal & $6(6.4)$ \\
\hline \multirow{2}{*}{$\begin{array}{l}\text { Kronik böbrek } \\
\text { hastalığ } 1 \\
(\mathrm{KBH})\end{array}$} & Yok & $22(23.2)$ \\
\hline & Var & 73 (76.8) \\
\hline \multirow{7}{*}{$\begin{array}{l}\cdot \text { Kronik } \\
\text { böbrek } \\
\text { hastallğ } 1 \\
\text { nedeni }(\mathrm{n}=73)\end{array}$} & Diyabet & $33(45.2)$ \\
\hline & Hipertansiyon & $46(63.0)$ \\
\hline & Kronik glomerulonefrit & $12(16.4)$ \\
\hline & Ürolojik & 10 (13.7) \\
\hline & $\begin{array}{l}\text { Konjenital kistik böbrek } \\
\text { hastalığı }\end{array}$ & $1(1.4)$ \\
\hline & $\begin{array}{l}\text { Kollojen doku hastalığı ve } \\
\text { sistemik vaskülitler }\end{array}$ & $1(1.4)$ \\
\hline & Diğer & 16 (21.9) \\
\hline \multirow{6}{*}{$\begin{array}{l}\text { •KBH üzerine } \\
\text { ABH nedeni } \\
(n=73)\end{array}$} & Dehidratasyon & $12(16.4)$ \\
\hline & Obstruksiyon & $7(9.6)$ \\
\hline & Enfeksiyon & $19(26.0)$ \\
\hline & $\begin{array}{l}\text { Sebep olan hastalığın } \\
\text { aktifleşmesi }\end{array}$ & $3(4.1)$ \\
\hline & Metabolik nedenler & $8(11.0)$ \\
\hline & Nefrotoksik ilaç kullanımı & $2(2.7)$ \\
\hline \multirow[t]{3}{*}{ Diürez } & Normal & $45(47.4)$ \\
\hline & Oligurik & $26(27.4)$ \\
\hline & Anürik & 24 (25.3) \\
\hline
\end{tabular}

\section{TARTIŞMA}

Çalışmamızda acil servise başvurup $\mathrm{ABH}$ tanısı alan hemodiyaliz endikasyonu konulup ilk kez diyalize giren 95 hastanın verileri incelenmiştir. Ülke çapında yapılan bir çalışmada ilk kez diyalize alınan akut ve kronik böbrek hastalığı olan hastaların \%57.52'si erkek, \%42.48'i kadındır. Hastaların yaş ortalaması ağırlıklı olarak \%39.34 ile 45-64 arasındadır (6). Çalışmamıza dâhil olan hastaların \%37.9'u kadın, \%62.1'i erkek olup ülke geneline benzer dağılmıştır. Çalışmamıza dâhil olan hastaların yaş ortalama değeri 62.28 \pm 15.96 ile 18-97 yaş aralığında olup ülke ortalamasına göre yüksek saptanmıştır. Bu durum 65 yaş üstü hastaların $\mathrm{ABH}$ gelişmesine daha yatkın olduğundan olabilir (7).

Diyaliz üremik komplikasyonlar, tedaviye dirençli hiperkalemi, asidoz ve aşırı volüm yüklenmesi durumlarında erken dönemde hastalara uygulanması gereken bir tedavi şeklidir. 2016 Yılı Ulusal Nefroloji, Diyaliz ve Transplantasyon Kayıt Sistemi Raporuna göre, ülkemizde hemodiyalize başlanan hastaların \%66.44'ü acil olarak hemodiyalize alınmıştır. Bu hastalarda en s1k diyalize başlama sebepleri hipervolemi (\%40) ve hiperpotasemidir (\%25) (8).

Amerika Birleşik Devletleri'nde SDBH olan 530.000 civarında kişi olduğu düşünülmektedir ve insidans oranı bir milyon nüfus başına yılda 350'dir. İnsidans oranının Afrika kökenlilerde yılda 1000'e kadar çıktığı bildirilmiştir (9). ABD'de diyalize başlanan yeni tanı SDBH larının \%55'inde altta yatan hastalık Diyabetes Mellitus'tur. \%33'lük kısmının ise hipertansiyona bağlı olduğu düşünülmektedir. Glomerulonefritler, polikistik böbrek hastalığı ve obsrüktif üropatiler diğer nedenlerdir (9). Türkiye Ulusal Nefroloji, Diyaliz ve Transplantasyon Kayıt Sistemi Raporlarına göre 2016

Tablo 4: Demografik Özellikler ve Başvuru Şikâyetlerine Göre Mortalitenin Değerlendirilmesi

\begin{tabular}{|c|c|c|c|c|}
\hline & & \multicolumn{2}{|c|}{ Mortalite } & \multirow[b]{3}{*}{$\mathrm{P}$} \\
\hline & & Yok $(n=56)$ & $\operatorname{Var}(n=39)$ & \\
\hline & & $\mathrm{n}(\%)$ & $\mathrm{n}(\%)$ & \\
\hline \multicolumn{5}{|l|}{ Demografik özellikler } \\
\hline \multirow{2}{*}{ Yaş (yıl) } & Min-Mak (Medyan) & $18-96(59)$ & $39-97$ (68) & ${ }^{\mathrm{a}} 0.001 * *$ \\
\hline & Ort \pm SD & $58.02 \pm 15.99$ & $68.41 \pm 13.97$ & \\
\hline \multirow[t]{2}{*}{ Cinsiyet } & Kadın & $21(37.5)$ & $15(38.5)$ & b 0.924 \\
\hline & Erkek & $35(62.5)$ & $24(61.5)$ & \\
\hline \multicolumn{5}{|l|}{ Başvuru şikâyetleri } \\
\hline \multirow[t]{2}{*}{ Şikâyet } & Yok & $3(5.4)$ & $0(0)$ & ${ }^{\mathrm{d}} 0.266$ \\
\hline & Var & $53(94.6)$ & $39(100)$ & \\
\hline \multirow[t]{6}{*}{ Görülen şikâyetler (n=92) } & Bulant1-kusma & $22(41.5)$ & $10(25.6)$ & b0.114 \\
\hline & Nefes darlığg & $9(17.0)$ & $6(15.4)$ & b0.838 \\
\hline & Halsizlik & $14(26.4)$ & $9(23.1)$ & b 0.715 \\
\hline & Dizüri ve idrarda azalma & $5(9.4)$ & $2(5.1)$ & d0.695 \\
\hline & Genel durum bozukluğu & $0(0)$ & $10(25.6)$ & ${ }^{\mathrm{d}} 0.001 * *$ \\
\hline & Diğer & $14(26.4)$ & $12(30.8)$ & b0.647 \\
\hline $\begin{array}{l}\text { a Student Test } \\
\text { - Birden cok secenek isaretlenmis }\end{array}$ & b Pearson Ki-kare Test & $d$ Fisher's Exa & & $k * p<0.01$ \\
\hline
\end{tabular}


yılında Türkiye'de RRT insidansı, çocuk hastalar da dâhil milyon nüfus başına 140 olarak hesaplanmıştır. Ülkemizdeki hastaların etyolojilerine bakıldığında \%38.5 diyabet, \%24.55 hipertansiyon, \%6.33 glomerulonefrit, \%4.16 polikistik böbrek hastalı̆̆ ve \%6 oranında da diğer sebeplerin olduğu görülmüştür (8). Çalışmamızda ise, \%63.0'ünün hipertansiyon, \%45.2'sinin diyabet \%16.4'ünün kronik glomerulonefrit, \%13.7'sinin ürolojik nedenler, \%1.4'ünün konjenital kistik böbrek hastalığ1, \%1.4'ünün kollojen doku hastalığı ve sistemik vaskülitler, \%21.9'unda ise diğer nedenler olduğu saptanmıştır.

ABH'a sebebin yerine göre en s1k prerenal ABH (\%55$60)$, renal ABH (\%35-40), postrenal ABH (\%5'den az) olarak üçe ayrılır. İskemik ya da nefrotoksik nedenler sonucu gelişen akut tübüler nekroz (ATN) renal ABH'ın \%90'dan fazlasını oluşturur. Koç ve arkadaşları yaptıkları ABH nedeniyle hemodiyalize alınan, öncesinde böbrek hastalığı olmayan hastaların etyolojilerine baktıkları çalışmada en sık akut tubuler nekroz (\%38) ve prerenal sebeplerin (\%11.8) olduğunu saptamışlardır (10). Bu çalışmada ise hemodiyalize alınan $\mathrm{ABH}$ hastalarının \%79.8 prerenal, \%13.8 renal, \%6.4 postrenal sebepler olduğu görülmüştür. Gong Yu ve ark. yaptıkları bir çalışmada, ABH'nın ana sebebinin (\%53) iskemi (hipovolemi, hipotansiyon), sepsis, nefrotoksisite ve post renal komplikasyonlara ilerleyen risk faktörlerinin (\%10-35) olduğunu göstermişlerdir (11).

ABH genellikle geri dönüşümlüdür. Bununla birlikte,
$\mathrm{ABH}$ hastanede yatan hastalarda, özellikle ileri yaşta, eşlik eden komorbid hastalıklar nedeniyle mortalite ve morbiditenin önemli sebeplerinden biridir $(12,13)$. Biyomedikal teknoloji gelişmelerine rağmen $\mathrm{ABH}$ 'da ölüm oranları halen azalmamış olup, \%15-60 civarındadır (14). ABH hastalarının mortalite oranı altta yatan hastalığa bağlı \%88'e kadar çıkabilir (15). İngiltere'de $\mathrm{ABH}$ sebebiyle diyalize alınan, daha önce KBH olmayan 1095 hasta prospektif olarak 10 yıllık bir süreçte takip edilmiş, diyaliz sonrası ilk 3 ayda toplam sağ kalımın \%59.5 olduğunu, ABH nedeniyle diyalize alınan hayatta kalan hastaların \%16.7 sinin diyaliz bağımlı olduğu görülmüştür (16). Almanya'da yapılan bir çalışmada da ABH sebebiyle hemodiyalize alınan 979 hastanın uzun dönem sonuçları değerlendirildiğinde, hastaların \%69'unun hastanede exitus olduğu, 6 ay sonraki sonuçlarda taburcu olan 301 hastanın \%51'nin yaşadığı, \%10 hastanın kronik diyaliz hastası olduğu görülmüştür $(13,15)$. Çalışmamızda ABH nedeniyle hemodiyalize alınan hastaların mortalite oranı ilk 30 günde $\% 41.1$ saptanmıştır. Hastaların \%64.2'sinde diyalize bağıml KBH olmuşken, \%28.4'sinde diyalize bağlı olmayan $\mathrm{KBH}, \% 7.4$ 'ünde tam iyileşme olduğu görülmüştür.

Kronik böbrek hastaları da bazen akut böbrek hasarı nedeniyle hastaneye yatmakta ve hemodiyalize alınmaktadırlar. Hsu ve arkadaşlarının yaptıkları bir çalışmada RRT ihtiyacı olmayan 1061 KBH'nın ABH sebebiyle hastaneye yatışı sonrasında \%26 hastanın hastaneye yatışında, \%4 hastanın daha 30 gün içinde exitus olduğu, \%49'unun SDBH olduğu saptanmıştır

Tablo 5: Diyaliz Endikasyonları ve Ek Hastalıklara Göre Renal Durumun Değerlendirilmesi

\begin{tabular}{|c|c|c|c|c|c|}
\hline & & \multicolumn{3}{|l|}{ Renal durum } & \multirow[b]{3}{*}{$\mathrm{p}$} \\
\hline & & $\begin{array}{l}\text { Tam iyileşme } \\
(\mathrm{n}=7)\end{array}$ & $\begin{array}{l}\text { Diyaliz ihtiyacı (-) } \\
\text { KBY }(n=27)\end{array}$ & $\begin{array}{l}\text { Diyaliz ihtiyacı }(+) \\
\text { KBY }(n=61)\end{array}$ & \\
\hline & & $\mathrm{n}(\%)$ & $\mathrm{n}(\%)$ & $\mathrm{n}(\%)$ & \\
\hline \multirow[t]{6}{*}{$\begin{array}{l}\text { Diyaliz } \\
\text { endikasyonları }\end{array}$} & $\begin{array}{l}\text { Metabolik asidoz ve kreatinin } \\
\text { yüksekliği }\end{array}$ & 3 (42.9) & $19(70.4)$ & $50(82.0)$ & " $0.044^{*}$ \\
\hline & Hiperkalemi & $0(0)$ & $3(11.1)$ & $5(8.2)$ & ${ }^{\mathrm{e}} 0.840$ \\
\hline & Hipervolemi & $2(28.6)$ & 7 (25.9) & $13(21.3)$ & b 0.840 \\
\hline & Postrenal ABH & $0(0)$ & $0(0)$ & $3(4.9)$ & ${ }^{\mathrm{e}} 0.647$ \\
\hline & Hiperkalsemi & $2(28.6)$ & $3(11.1)$ & $0(0)$ & ${ }^{\mathrm{e}} 0.002 * *$ \\
\hline & $\begin{array}{l}\text { Üremik semptomlar ve } \\
\text { perikardit }\end{array}$ & $0(0)$ & $6(22.2)$ & $4(6.6)$ & ${ }^{\mathrm{e}} 0.082$ \\
\hline \multirow[t]{7}{*}{ Ek hastalıklar } & Malignite & $2(28.6)$ & $9(33.3)$ & $15(24.6)$ & 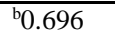 \\
\hline & Hipertansiyon & $1(14.3)$ & $12(44.4)$ & $28(45.9)$ & ${ }^{\mathrm{e}} 0.358$ \\
\hline & Diyabet & $1(14.3)$ & $11(40.7)$ & $19(31.1)$ & ${ }^{\mathrm{e}} 0.465$ \\
\hline & Kardiak hastalıklar & $3(42.9)$ & 7 (25.9) & $16(26.2)$ & b0.634 \\
\hline & Renal parenkimal hastalıklar & $1(14.3)$ & 14 (51.9) & $34(55.7)$ & ${ }^{\mathrm{e}} 0.114$ \\
\hline & Postrenal nedenler & $0(0)$ & $0(0)$ & $8(13.1)$ & ${ }^{\mathrm{e}} 0.106$ \\
\hline & Diğer hastalıklar & $1(14.3)$ & $5(18.5)$ & $23(37.7)$ & ${ }^{\mathrm{e}} 0.139$ \\
\hline \multirow{2}{*}{$\begin{array}{l}\text { Acil serviste } \\
\text { yatış (gün) }\end{array}$} & "Min-Mak (Medyan) & 1-9(4) & 1-22(5) & $0-36(5)$ & 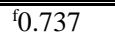 \\
\hline & Ort \pm SD & $4.00 \pm 2.58$ & $5.70 \pm 4.69$ & $6.67 \pm 6.87$ & \\
\hline \multicolumn{2}{|c|}{$\begin{array}{l}\text { bPearson Ki-kare Test } \\
* p<0.05 \\
\cdot \text { Birden cok secenek isaretlenmistir }\end{array}$} & Freeman-Haltc & Exact Test & uskal Wallis Test & \\
\hline
\end{tabular}


(17). Çalışmamızdaki diyalize girmeye başladıktan sonraki 30 gün içinde ex olan $\mathrm{KBH}$ olgularının $\% 16.4$ 'ünde dehidratasyon, \%9.6'sinda obstrüksiyon, \%26.0'sinda enfeksiyon, \%4.1'inde sebep olan hastalığın aktifleşmesi, \%11.0'inde metabolik nedenler, \%2.7'sinde nefrotoksik ilaç kullanımı sonucu $\mathrm{ABH}$ olduğu görülmektedir. $\mathrm{KBH}$ üzerine $\mathrm{ABH}$ olan olguların \%66.6'sı 30 gün içerisinde exitus olmuştur. $\mathrm{KBH}$ olmayan $\mathrm{ABH}$ nedeniyle diyalize alınan hastalar ile öncesinde $\mathrm{KBH}$ olan hastaların mortalite oranları benzerdir. Amerikada yapılan bir çalışmada, ulusal kayıt sisteminde 5 milyondan fazla yatan hastanın ICD kodları ile hastane yatışından önce $\mathrm{KBH}$ olmayan ABH'ların, öncesinde KBH olan hastalara göre mortalitesinin daha yüksek olduğu görülmüştür (18).

30 gün içinde exitus olan $\mathrm{ABH}$ olgularının \%82.1'i prerenal, \%12.8'i renal, \%5.1'i postrenal nedenlerle exitus olmuştur. Tam iyileşme gösteren \%14 olguda, diyaliz ihtiyacı olmayan KBH'ların \%51.9'u diyaliz ihtiyacı olan KBH'ların \%55.7'si renal parenkimal ek hastalığa sahip olduğu görüldü. 2007 yılı Türk Nefroloji Derneğine göre ABH'da en s1k mortalite nedenleri kardiyovasküler hastalıklar, enfeksiyon, solunum yetmezliği ve serebrovasküler olaylardır (19). Amerikada sadece acil durum söz konusu olduğunda diyalize alınabilen belgesiz göçmen 35 hastanın yer aldığı retrospektif çalışmada hastaların çoğunun kardiyovasküler nedenli öldügü görülmüştür (20). Bu çalışmada da en sık mortalite nedenleri \%64.1 altta yatan hastalık, \%30.8 kardiyovasküler hastalık, \%20.5 metabolik nedenler, \%17.9 enfeksiyon, \%2.6 serebrovasküler olaylar olarak elde edilmiştir (20).

ABH olan hastalarda mortaliteyi çeşitli faktörler etkilemektedir. Uzun dönemde yaş, cinsiyet, rrk, iskemik kalp hastalığı, KBH, diyabet, hipertansiyon gibi komorbid durumların bulunması mortalite riskini artırmaktadır (17). İleri yaşta olan hastalar ve en az bir komorbiditesi olan hastalarda mortalite anlamlı olarak daha yüksek bulunmuştur (13). 2005'te BEST Kidney çalışmasında yaş arttıkça $\mathrm{ABH}$ hastalarının mortalitesinin ilişkili olarak arttığ Bagshaw ve ark. Ayrıca yaşlı popülasyonda ilk ABH epizotundan sonraki 1 yil içinde mortalitenin daha yüksek olduğunu söylemişlerdir (21). Mehta ve ark. yaş ilerledikçe, RRT önermek konusunda meyilin azaldığını raporlamışlar (22). Diyaliz prosedürünün yaşlı popülasyonda mortalite üzerine etkisinin daha fazla olduğunu savunan çalışmalar da mevcuttur (23,24). Silveira Santos C.G. ve arkadaşlarının 60 yaş üstü popülasyonda Akut böbrek hasarını prospektif olarak gözlemledikleri çalışmada yaşın kayda değer bir şekilde mortaliteyle ilişkisi olmadığını, akut böbrek hasarı evresi ve diyaliz ihtiyacının olmasının kayda değer derecede mortalite ile ilişkisi olduğunu saptamışlardır. Ayrıca cinsiyet, hipertansiyon, diyabet, karaciğer hastalığı ve kalp yetmezliğinin önemli ölçüde mortalite üzerinde etkisi olduğu saptanmamıştır (25). Pascaul J ve ark. da genel popülasyonda akut böbrek hasarı prognozunu inceledikleri çalışmada diyaliz bağımlılığ 1 ve $\mathrm{ABH}$ derecesinin mortalite üzerinde bağımsız risk faktöreleri olduğunu savunmuşlardır (26). Çalışmamızda eksitus olan ABH hastalarının daha yaşlı olduğu görülmüştür. Genel durum bozukluğu ve bilinç bulanıklığı ile acil servise getirilen hastaların mortalite oranları yüksek bulunmuştur. Mortalite açısından cilt turgorunun azalmış olması, periferik ödemin olması, kreatinin değerlerinin düşük olması, oligürik olması mortaliteyi artıran diğer faktörler olarak bulunmuştur. Düşük EF, malignite, sepsis mortaliteyi ciddi artıran komorbid durumlardır. 618 diyalize alınan ABH hastasının yer aldığı bir çalışmada serum kreatinin seviyesinin düşük olması mortalite açısından anlamlı bulunmuştur. Aynı çalışmada \%64 hastada ileri yaş, karaciğer yetmezliği, solunum yetmezliği, sepsis ve trombositopeninin mortalite ile ilişkili olduğu saptanmıştır. Yüksek kan üre nitrojen düzeyi ile düşük serum kreatinin değerinin lojistik regresyon modellerinde mortalite ile ilişkili olduğu görülmüştür. $\mathrm{KBH}$ üzerine $\mathrm{ABH}$ olması mortalite açısından düşük risk, sepsis ise mortalite açısından yüksek riskli bulunmuştur (27). Kreatinin seviyesi düşük olan hastalarda mortalitenin yüksek çıkmasının sebebi hastaların klinik durumlarına bağlanmıştır. ABH olan hasta grubunda oral alım bozukluğu olan dehidrate ve komorbid hastalığı olan yaşlı hastaların varlığının, $\mathrm{KBH}$ olan hasta grubunda da katabolik sürece girmiş olan hastaların varlığının mortaliteyi artırdığ düşünülmüştür.

Çalışmamızda hastaların acil serviste yatış süreleri

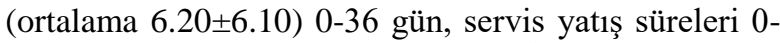

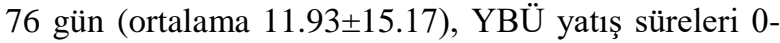
21 gün (ortalama 1.78 \pm 4.63 ) olduğu görülmüştür. Acil servis yatış süresi ile mortalite arasında istatistik olarak anlamlı ilişki bulunmamıştır. Mortalite görülen olgularda serviste yatış süresi daha düşüktür. Mortalite varlığına göre olguların YBÜ yatış süreleri arasında istatistiksel olarak anlamlı farklılık saptanmıştır ( $p=0.001 ; p<0.01)$; mortalite görülen olgularda YBÜ yatış süresi daha yüksektir. Silveira Santos CG. ve arkadaşlarının 60 yaş üstü popülasyonda Akut böbrek hasarını prospektif olarak gözlemledikleri çalışmada, acil servis yatış süresi uzadıkça mortalitenin artttığını gözlemlemişlerdir. Ölüm riskinin 6 günden uzun süreli yatışlarda anlamlı derecede arttığını tespit etmişlerdir (25).

Sonuç Olarak; Acil servise başvuran ve Akut böbrek hasarı saptanan pek çok hasta anüri, hipervolemi, hiperpotasemi ve üremik bulgular nedeniyle hemodiyalize alınmaktadır. Bu hastaların otuz günlük mortalite oranları yüksektir ve en sık mortalite sebebi malignite gibi altta yatan hastalıklara bağlı komplikasyonlardır.

Çıkar İlişkisi

Tüm yazarlar çıkar çatışması olmadığını beyan eder. 


\section{Phnx Med J. November, 2020. Volume 2 No 3}

\section{KAYNAKLAR}

1. Akpolat T, Utaş C. Hemodiyaliz hekimi el kitabı, Anadolu Yayıncılık, Kayseri, 2001. s. 15-34.

2. Kramer A, Pippias M, Noordzij M, Stel VS, Afentakis N, Ambühl PM, et al. The European Renal Association-European Dialysis and Transplant Association (ERA-EDTA) Registry Annual Report 2015: a summary. Clinical kidney journal. 2018;11(1):108-22.

3. Seyhani N, Ates K, Süleymanlar G. Türkiye’de renal replasman tedavilerinin güncel durumu: Türk Nefroloji Derneği Kayıt Sistemi 2016 Y1lı Özet Raporu. Turk Neph Dial Transpl 2018;27(2):133-139.

4. Singbartl K, Joannidis M. Short-term effects of acute kidney injury. Crit Care Clin. 2015;31(4):751-62.

5. Li PK, Burdmann EA, Mehta RL; World Kidney Day Steering Committee 2013. Acute kidney injury: global health alert. Kidney Int. 2013;83(3):372-6.

6. Bouchard J, Soroko SB, Chertow GM, Himmelfarb J, Ikizler TA, Paganini EP, et al. Fluid accumulation, survival and recovery of kidney function in critically ill patients with acute kidney injury, Kidney Int. 2009;76(4):422-7.7.

7. Hoste EAJ, et al. "Global epidemiology and outcomes of acute kidney injury." Nat Rev Nephrol. 2018;14(10): 607-625.

8. Süleymanlar, G. Registry of Nefrology, Dialysis and Transplantation in Turkey.Ministry of Health and Turkish Society of Nephrology Joint Report. 2017.

9. Harrison's Principles Of Internal Medicine, , Jameson J, Fauci AS, Kasper DL, Hauser SL, Longo DL, Loscalzo J,(editors),18th ed. Chapter. 280:2308-2331.

10. Koç Y, Abdulkadir Ünsal A, Hasan Kayabaşlı H, Akgün AO, Ahbap E, Mürvet Yılmaz M. Ve ark, İlk Kez Hemodiyaliz Tedavisine Alınan Hastaların Geriye Dönük Olarak Değerlendirilmesi. Ş.E.E.A.H. Tıp Bülteni. 2009:43;169-173.

11. Gong Y, Xu H, Zhang F, Hao C. Comparison of prognostic value of two kinds of severity scoring systems for hospital mortality prediction of elderly patients with acute kidney injury. Aging Clin Exp Res. 2012;24:74-78.

12. Mehta RL, McDonald B, Gabbai FB, Pahl M, Pascual MT, Farkas A. et al. Continuous vs. intermittent dialysis for acute renal failure in the ICU: Results from a randomized multicenter trial, Kidney Int. 2001;60(3):1154-63.

13. Morgera S, Kraft AK, Siebert G, Luft FC. Neumayer HH, Long-Term outcomes in acute renal failure patients treated with continuous renal replacement therapies. Am J Kidney Dis. 2002;40(2):275-9.

14. Ricci Z, Cruz D, Ronco C. The RIFLE criteria and mortality in acute kidney injury: A systematic review. Kidney Int. 2008;73(5):538-46.

15. Çeliker H. Akut böbrek yetmezliği epidemiyolojisi. Türk Nefroloji Diyaliz ve Transplantasyon Dergisi. 2006;15: 1-4.

16. Bhandar1 S. Turney Jh, Survivors Of Acute Renal Failure Who Do Not Recover Renal Function. Q J Med. 1996;89:415-421.

17. Hsu CY, Chertow GM, McCulloch CE, Fan D, Ordoñez JD, Go AS. Nonrecovery of kidney function and death after acute on chronic renal failure. CJASN. 2009;4(5):891-898.

18. Waikar SS, Curhan GC, Wald R, McCarthy EP, Chertow GM. Declining mortality in patients with acute renal failure, 1988 to 2002 . J Am Soc Nephrol. 2006;17(4):1143-50.

19. Süleymanlar G, Serdengeçti K, Erek E. Türkiye’de nefroloji- diyaliz ve transplantasyon registry 2007. 1.Bask1, İstanbul: Yorum Danışmanlık. 2008. s: 3-23.

20. Cervantes L, O’Hare A, Chonchol M, Hull M, Bockern JV, Thomson M, et al. Circumstances of death among undocumented immigrants who rely on emergency-only hemodialysis. Clin J Am Soc Nephrol. 2018;13:1405-1406.

21. Bagshaw SM, Laupland KB, Doig CJ, Mortis G. Prognosis for long-term survival and renal recovery in critically ill patients with severe acute renal failure: Population-based study. Crit Care. 2005;9:700-709.

22. Mehta RL, Kellum JA, Shah SV, Molitoris BA. Acute kidney injury network:acute kidney injury network: report of an initiative to improve outcomes in acute kidney injury. Crit Care. 2007;11:31.

23. Wang JH, Joslin J, Jenkins R, Sharpe CG. Outcomes of elderly patients with acute kidney injury on a renal high dependency unit. int. J. Clin Pract. 2015;69:1209-1210.

24. Kane-Gill SL, Sileanu FE, Murugan R, Trietley GS. Risk Factors for acute kidney injury in older adults with critical illness: a retrospective cohort study. Am J Kidney Dis. 2015;65:860-869.

25. Silveira Santos CG, Romani RF, Benvenutti R, Ribas Zahdi JO, Riella MC, Mazza do Nascimento M. Acute kidney injury in elderly population: a prospective observational study, Nephron Clinical Practice. 2018;138:104-112.

26. Pascual J, Liona F. Causes and prognosis of acute renal failure in the very old. madrid acute renal failure study group. J Am Geriatr Soc. 1998;46:721-725.

27. Chertow GM, Soroko SH, Paganini EP, Cho KC, Himmelfarb J, Ikizler TA, Mehta R. Mortality after acute renal failure: models for prognostic stratification and risk adjustment, Kidney Int. 2006;70(6):1120-6. 